Indexed by

\title{
Scopus
}

\section{ECONOMIC EFFECT CALCULATION FROM NEW FLAXSEED SOLUTION FOR ROAD DUST SUPPRESSION DURING OPEN PIT MINING IN ALEXEEVSKY CEMENT DEPOSIT IN MORDOVIA. CASE STUDY}

Crossref

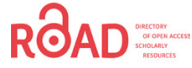

Marina Zhulina

National Research Mordovia

State University, Saransk,

KOBSON

Russian Federation

Key words: dust suppression, open pit mining, technological roads irrigation, calculation of costs, SWOT analysis, economic efficiency

doi:10.5937/jaes0-30037

Cite article:

Zhulina, M. (2021) ECONOMIC EFFECT CALCULATION FROM NEW FLAXSEED SOLUTION FOR ROAD DUST SUPPRESSION DURING OPEN PIT MINING IN ALEXEEVSKY CEMENT DEPOSIT IN MORDOVIA. CASE STUDY, Journal of Applied Engineering Science, 19(3), 743-749, DOI:10.5937/jaes0-30037

Online aceess of full paper is available at: www.engineeringscience.rs/browse-issues 


\title{
ECONOMIC EFFECT CALCULATION FROM NEW FLAXSEED SOLUTION FOR ROAD DUST SUPPRESSION DURING OPEN PIT MINING IN ALEXEEVSKY CEMENT DEPOSIT IN MORDOVIA. CASE STUDY
}

\author{
Marina Zhulina \\ National Research Mordovia State University, Saransk, Russian Federation
}

A method is proposed to reduce dust formation from technological roads during open pit mining. It is suggested to use a solution based on flaxseed cake, instead of only water, for irrigation the technological roads. It can wet the roads more efficiently. The frequency of watering can be significantly decreased, thereby the employees working time can be optimized to reduce harmful effects on health. The costs for oil and fuel also will be decreased. The calculation of costs included the cost of labor, electricity, fuel for the sprinkler, repairs, depreciation and others. Also, a SWOT analysis of the project was performed to justify possible risks, including economic ones, associated with the implementation and application of the proposed method. It was calculated, an economic effect can be achieved in amount of about 1.5 million rubles per year at the Alexeevsky enterprise.

Key words: dust suppression, open pit mining, technological roads irrigation, calculation of costs, SWOT analysis, economic efficiency

\section{INTRODUCTION}

Dust load on the atmosphere is one of the challenges to civilization [1]. Different techniques are used for assessing the environment load, e.g. computer modeling is widespread [2]; [3], in addition to field research [4]. Mining operations are not only time-consuming but have a side effect connected with utilization of technical waste [5]. Cement production is a process with high load to the environment, especially air [6]. An urgent problem is to enhance energy and ecological efficiency of the mines [7]; [8].

Different agents for dust suppression during open pit coal mining are proposed in present time: copolymer of hydroxyethyl cellulose with acrylamide and acrylic acid [9]; gelatin-like substances derived from sodium lignin sulfonate and acrylic acid [10], enhanced by adding wetting agent dodecyl dimethyl betaine [11]; the agent based on hydroxypropyl guar gum [12]; soybean protein isolate and sodium dodecyl sulfate 13], etc. To produce these wetting agents, few polymerization stages are necessary.

It can be proposed probably a cheaper and more simple way to make the dust suppression agent. The studied solution was made from flaxseed cake waste. The global flaxseeds market is projected to grow steadily with Russia's share for $16 \%$ in oilseed flax (not far from leading Kazakhstan) [14]; [15]. Utilizing flaxseed in food processing is challenging, due to presence of cyanogenic glucosides [16]; but promising, because of high protein content [17]. Flaxseed can be utilized for oil production through pressing and separation. During the process, the flaxseed cake is formed [18]. This cake can be used as animal feed or fertilizer, and we propose to use the cake in dust suppression process.
Alexeevsky cement deposit belongs to the Eurocoment Group - the largest cement manufacturer in Russia which is in Top 5 cement companies in the world [19]. The production capacity of Eurocement Group is more than 60 million tons of cement per year, and the share of Mordovcement is about $17 \%$. Therefore, the enterprise that owns the Alexeevsky cement deposit is the largest cement plant in Russia. The use of proposed solution for road dust suppression can leads to a significant economy for the enterprise. One of the most often used technology for road dedusting is in mixing soils with bitumen. The disadvantage of this way is in complexity of technological processing. The proposed solution looks like more ecological way for road dedusting.

In Europe, total production of EU28 and Cembureau is about 300 million tons of cement and clinker [20]. The possible use of proposed solution for technological road dedusting can leads to significant economical effect.

Moreover, the proposed methodology for dedusting can be considered within the framework on Nature-based solutions (NBS) conception-the strategy which uses actions copied from nature to address different environmental challenges [21]. The co-benefits of using proposed project may consist in ecological connectivity and improvement the health and quality of life [22]. Implementing of new project will effectively contribute to sustainable economic growth [23].

\section{METHODOLOGY}

\section{Operating schedule}

During water irrigation, according to the current method, it 
Table 1: Operating schedule for hydro-irrigation

\begin{tabular}{|c|c|c|c|c|c|c|c|c|c|c|}
\hline \multirow{2}{*}{ Process } & \multirow{2}{*}{ Duration, $\min$. } & \multicolumn{9}{|c|}{ Shift hour } \\
\hline & & \begin{tabular}{l|l|}
8 & 9 \\
\end{tabular} & 0 & $\pi$ & 12 & $\begin{array}{ll}B 3 \\
B 2\end{array}$ & 5 & 16 & $\begin{array}{ll}7728 \\
7\end{array}$ & \begin{tabular}{l|l}
1819 \\
\end{tabular} \\
\hline Watering & 75 & -6 & $\square$ & & - & - & -6 & - & -1 & 近 \\
\hline Rest, tank filling others & 15 & $\square$ & - & & ] & L & $\square$ & - & U & 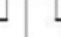 \\
\hline
\end{tabular}

Table 2: Operating schedule if use proposed solution instead of water

\begin{tabular}{|c|c|c|c|c|c|c|c|c|c|c|c|c|}
\hline \multirow{2}{*}{ Process } & \multirow{2}{*}{ Duration, $\min$} & \multicolumn{11}{|c|}{ Shift hour } \\
\hline & & 8 & 9 & 0 & $\pi$ & & & 14 & & $\begin{array}{ll}16 & 17 \\
\end{array}$ & & 88 \\
\hline Watering & 75 & - & & & & - & & & & - & & \\
\hline Rest, tank filling others & 165 & & - & & - & & - & & - & L & & \\
\hline
\end{tabular}

is necessary to treat the roads once every 1.0-1.5 hours, while the use of proposed composition can reduce the frequency of watering to 1 time every 3-4 hours. In this case, the operating schedule of a worker employed on irrigation equipment changes greatly. Operating schedules are presented in Tables 1 (current) and 2 (for new project).

It can be seen from Table 1, that during a 12-hour shift, an employee must spill water on technological roads for 8 times, which, in turn, leads to an escalation of wear and tear on equipment, as well as deterioration of the employee's health due to increased monotonous loads and frequent interaction with a harmful work environment. Moreover, such frequent detours mean a significant increase in the economic cost of dump truck fuel.

It can be seen from Table 2, the appearance of additional free time for an employee engaged in irrigation work makes it possible, for example, to carry out maintenance and inspection of equipment at this time, which will allow timely detection and elimination of any malfunctions and increase the resource of the unit.

The flaxseed cake solution ( $2 \%$ ) was prepared by dilution flaxseed cake (2 weight parts) in water (98 weight parts) [24].

\section{Calculation of labor costs}

During a work shift, the irrigation specialist must go around the section of technological roads for several times. The frequency of watering the roads is determined by the method of dust suppression. The length of the road section and the time required to drive it through are also taken into account. Therefore, shift labor costs can be determined by the ratio:

$L C_{s h}=S_{h} \times N_{w} \times T_{w}$

where:

$L C_{s h}$-shift labor costs;

$S_{h}$-irrigation specialist's hourly rate,rubles/ $h$;

$N_{w}$-number of waterings per shift;

$T_{w}$-duration of the road section watering, $\mathrm{h}$.

The duration of treatment of the road section with irrigation machine depends on the section length, and the vehicle speed during watering:

\section{Proposed solution}

$T_{w}=\frac{L_{s}}{V_{o p}}$

where:

$L_{S}$ is the road section length, $\mathrm{km}$;

$V_{o p}$-the average operating speed of irrigation equipment, $\mathrm{km} / \mathrm{h}$.

The number of waterings of the technological road section depends on the duration of one operating cycle and shift, the time spent on the tank loading, rest and other auxiliary operations:

$N_{w}=\frac{T_{\text {sh }}}{\left(T_{w}+T_{\text {aux }}\right)}$

where:

$T_{s h}$ is the duration of one shift, $\mathrm{h}$;

$T_{\text {aux }}$-the time required for rest, tank loading and other operations, $\mathrm{h}$.

Since the working day at the enterprise is divided into 2 shifts of 12 hours each, and also if consider that the enterprise works 355 days a year, it is possible to calculate the annual costs of the enterprise for irrigation measures in terms of wages using the following equation:

$L C_{\text {year }}=710 \times L C_{\text {sh }}$

where:

$L C_{\text {year }}$-year labor costs of enterprise.

The enterprise must pay the fees for the employee to the insurance funds:

$I F_{\text {year }}=L C_{\text {year }} \times S$

where $S-$ share of payment to the Fund $(34.1 \%)$.

\section{Calculation of electricity costs}

Shift energy costs for filling the tank of the irrigation machine using submersible pump:

$E_{\text {sh }}=P \times T \times N \times C_{E}$

where:

P-pump power, kWt;

T-pump operation time for 1 filling, $\mathrm{h}$;

$\mathrm{N}$-number of sprinkler tank fillings per shift;

$C_{E}$-electrical energy cost, rubles $/ \mathrm{kWt} \mathrm{t}^{\star} \mathrm{h}$.

Energy costs per year $\mathrm{E}_{\text {year }}$ :

$E_{\text {year }}=710 \cdot E_{\text {sh }}$

\section{Calculation of fuel costs}

Technological roads in quarries and open-pit mines often have a considerable length. Therefore, dump trucks and sprinklers diesel costs represent one of the largest contributors to total operating costs in technological process. Shift diesel costs for irrigation machine:

$F_{s h}=C_{F} \times D \times \frac{T_{W} \times L_{S}}{100}$

where:

$C_{F}$-diesel cost, rubles/l;

Istraživanja i projektovanja za privredu ISSN 1451-4117 
D-diesel consumption per $100 \mathrm{~km}, \mathrm{I}$.

Year diesel costs:

$F_{\text {year }}=710 \times F_{\text {sh }}$

\section{Irrigation machine maintenance costs}

In most cases, the reliability of machines and mechanisms is ensured by the timely replacement of lubricating fluids and additives, which usually provides an increase in the service life of equipment by $30-50 \%$.

Also, one of the indicators of machine reliability is the mean time between failures, which reflects the approximate possible frequency of breakdowns and malfunctions in the unit.

Shift equipment maintenance costs:

$R_{s h}=R_{\text {aver }} \frac{T_{s h}^{\text {use }}}{T_{F}}+C_{O} \times O \times \frac{L_{S} \times N_{W}}{100}$

where:

$R_{\text {aver }}$-average repairing costs for irrigation machine;

$T_{\text {sh }}$ use-actual estimated time of machine use per shift;

$T_{F}$-mean time between failures;

$C_{O}$-average cost of engine oil;

O-average consumption of engine oil per $100 \mathrm{~km}$, I.

Average consumption of engine oil is usually taken as $0.25-0.3 \%$ from fuel consumption [25]. We take as $0.3 \%$ $\mathrm{O}=0.003 \times D$

Year irrigation machine maintenance costs:

$R_{\text {year }}=R_{\text {aver }} \frac{T_{\text {year }}^{\text {use }}}{T_{F}}+710 \times C_{O} \times O \times \frac{L_{S} \times N_{W}}{100}$

where:

$T_{\text {year }}$ use - actual estimated time of machine use per year, $\mathrm{h}$.

$T^{\text {use }}=T_{W} \times N_{w} \times N_{d} \times N_{s h}$

where:

$N_{d}$-number of days in the reporting period;

$N_{s h}$-number of shifts in the reporting period.

\section{Irrigation product costs}

Hydro-irrigation is the main and most common method of dust suppression in open pit mining due to the availability of water at the enterprise. The Alexeevsky cement deposit has its own internal reservoir, which meets the needs of the entire enterprise in water. Therefore, there is no cost for irrigation fluid in the case of hydro-irrigation. For the manufacture of the proposed solution, organic raw materials are needed, namely, flax production waste - flaxseed cake. Thus, the cost of purchasing raw materials will be the cost of the solution itself, excluding the technology of its production.

Shift irrigation solution costs:

$P_{s h}=C_{i} \times V \times N_{W}$ where:

$\mathrm{C}_{i}$-irrigation solution cost;

V-sprinkler tank volume.

Year irrigation solution costs:

$P_{\text {year }}=710 \times P_{\text {sh }}$

\section{Depreciation costs}

When using machinery and equipment, part of its cost is gradually transferred to products that were produced using this equipment.

Considering that depreciation rate is $10 \%$ of the initial cost, the annual sprinkler depreciation will be determined by following equation:

$A_{\text {year }}=0.1 \times C_{s}$

where:

$C_{S}$-initial cost of sprinkler machine.

\section{Total costs}

Total costs:

$C_{\text {total }}=L C_{\text {year }}+I F_{\text {year }}+E_{\text {year }}+F_{\text {year }}+R_{\text {year }}+P_{\text {year }}+A_{\text {year }}$

Economic effect of the project will be determined by the difference in costs before the proposed innovations implementation and after their application.

$E E=C_{\text {total }}^{1}-C_{\text {total }}^{2}$

where:

$C_{t \text { otal }}^{1}$-current total costs;

$C_{t \text { otal }}^{2}$-total costs in new project.

\section{RESULTS AND DISCUSSION}

\section{Calculation of labor costs}

Rubles Initial data for calculating the labor costs are shown in Table 3.

Table 3: Initial data for calculating the labor costs

\begin{tabular}{|c|c|}
\hline Parameter & Value \\
\hline Specialist's hourly rate $\mathrm{S}_{\mathrm{h}}$, rubles/h & 230 \\
\hline Road section length $\mathrm{L}_{\mathrm{s}}, \mathrm{km}$ & 25 \\
\hline Average operating speed $\mathrm{V}_{\text {op }}, \mathrm{km} / \mathrm{h}$ & 20 \\
\hline Shift duration $\mathrm{T}_{\text {sh }}, \mathrm{h}$ & 12 \\
\hline Duration of auxiliary operations $\mathrm{T}_{\text {aux }}, \mathrm{h}$ & 0.3 \\
\hline
\end{tabular}

As can be calculated from the above Table 1, the duration of the road section watering $T_{w}$ (from Eq. 2):

$T_{w}=\frac{25}{20}=1.25 h$

The number of waterings of the technological road section (from Eq. 3):

$N_{w}=\frac{12}{(1.25+0.3)}=8$

Using the proposed solution instead of water for watering 
leads to decrease in waterings quantity:

$N_{w}^{\sim}=\frac{12}{(1.25+2.75)}=3$

Shift labor costs if use water as watering agent (from Eq. 1): $L C_{\text {sh }}=230 \cdot 8 \cdot 1.25=2225$.8rubles

Shift labor costs if use proposed solution as watering agent (from Eq. 1):

$L C_{\text {sh }}^{\sim}=230 \cdot 3 \cdot 1.25=862.5$ rubles

Year labor costs of enterprise if use water as watering agent (From Eq. 4):

$L C_{\text {year }}=710 \cdot 2225.8=1580323$ rubles

Year labor costs of enterprise if use proposed solution as watering agent (From Eq. 4):

$L C_{\text {year }}^{\sim}=710 \cdot 862.5=612375$ rubles

Fees to the insurance funds if use water as watering agent (from Eq. 5):

$I F_{\text {year }}=1580323 \times 0.341=538890$ rubles

Fees to the insurance funds if use proposed solution as watering agent (from Eq. 5):

$I F_{\text {year }}^{\sim}=612375 \times 0.341=208819.9$ rubles

\section{Calculation of electricity costs}

Rubles Initial data for calculating electrical energy costs are shown in Table 4.

Table 4: Initial data for calculating the electrical energy costs

\begin{tabular}{|c|c|}
\hline Parameter & Value \\
\hline Electrical energy cost $C_{E}$, rubles/kWh & 3.28 \\
\hline Pump power $P, \mathrm{~kW}$ & 100 \\
\hline Pump operation time $T, \mathrm{~h}$ & 0.25 \\
\hline
\end{tabular}

Shift energy costs from Eq. 6 if use water as watering agent: $E_{s h}=100 \times 0.25 \times 8 \times 3.28=656$ rubles

Shift energy costs from Eq. 6 if use proposed solution as watering agent:

$E_{s h}^{\sim}=100 \times 0.25 \times 3 \times 3.28=246$ rubles

Year energy costs from Eq. 6 if use water as watering agent: $E_{s h}=710 \times 656=465760$ rubles

Year energy costs from Eq. 6 if use proposed solution as watering agent:

$E_{s h}=710 \times 246=174660$ rubles

\section{Calculation of fuel costs}

Rubles Initial data for calculating fuel costs are shown in Table 5.

Table 5: Initial data for calculating fuel costs

\begin{tabular}{|c|c|}
\hline Parameter & Value \\
\hline Average cost of diesel fuel $C_{F}$, rubles/l & 50 \\
\hline $\begin{array}{c}\text { Average diesel consumption per } 100 \mathrm{~km} \text { (for } \\
\text { KamAZ 55111) } D, \mathrm{I}\end{array}$ & 25 \\
\hline
\end{tabular}

Shift energy costs from Eq. 8, if use water as watering agent:

$F_{\text {sh }}=50 \times 25 \times \frac{25 \times 8}{100}=2500$ rubles

Shift energy costs from Eq. 8, if use proposed solution as watering agent:

$F_{s h}=50 \times 25 \times \frac{25 \times 3}{100}=937.5$ rubles

Year energy costs from Eq. 9, if use water as watering agent:

$F_{\text {year }}=710 \times 2500=1775000$ rubles

Year energy costs from Eq. 9, if use water as watering agent: $F_{\text {year }}=710 \times 937.5=665625$ rubles

\section{Irrigation machine maintenance costs}

Initial data for calculating maintenance costs are represented in Table 6.

Table 6: Initial data for calculating maintenance costs

\begin{tabular}{|c|c|}
\hline Parameter & Value \\
\hline $\begin{array}{c}\text { Average cost of the equipment repairing } \\
R_{\text {aver }} \text {, rubles }\end{array}$ & 15000 \\
\hline Mean time between failures $T_{F}, \mathrm{~h}$ & 300 \\
\hline Average cost of engine oil $C_{O}$, rubles / I & 750 \\
\hline
\end{tabular}

Shift maintenance costs from Eq. 10 if use water as watering agent:

$R_{\text {sh }}=15000 \times \frac{1.25 \times 8 \times 1 \times 1}{300}+750 \times 0.003 \times 25 \times \frac{25 \times 8}{100}=612.5$ rubles

Shift maintenance costs from Eq. 10 if use proposed solution as watering agent:

$R_{\text {sh }}=15000 \times \frac{1.25 \times 3 \times 1 \times 1}{300}+750 \times 0.002 \times 25 \times \frac{25 \times 3}{100}=230$ rubles

Year maintenance costs from Eq. 11 if use water as watering agent:

$R_{\text {year }}=15000 \times \frac{1.25 \times 8 \times 355 \times 2}{300}+710+750 \times 0.003 \times 25 \times \frac{25 \times 8}{100}=434875$ rubles Year maintenance costs from Eq. 11 if use proposed solution as watering agent:

$R_{\text {year }}=15000 \times \frac{1.25 \times 3 \times 355 \times 2}{300}+710+750 \times 0.003 \times 25 \times \frac{25 \times 3}{100}=163078$ rubles

\section{Irrigation product costs}

The average market value of flaxseed cake and other initial data for the calculation for the section are presented in Table 7.

Table 7: Initial data for calculating the costs of irrigation solution

\begin{tabular}{|c|c|}
\hline Parameter & Value \\
\hline Raw material cost $C_{i}$, rubles / I & 0.09 \\
\hline Sprinkler tank volume $V, I$ & 7500 \\
\hline
\end{tabular}


Shift irrigation costs from Eq. 14 if use water as watering agent:

$P_{\text {sh }}=0.09 \times 500=2025$ rubles

Year irrigation costs from Eq. 15 if use proposed solution as watering agent:

$P_{\text {year }}=710 \times 2025=1437759$ rubles

\section{Depreciation costs}

Initial data for calculating depreciation costs are represented in Table 8.

Table 8: Initial data for calculating depreciation costs

\begin{tabular}{|c|c|}
\hline Parameter & Value \\
\hline Initial cost of sprinkler machine $C_{S}$, rubles & 5000000 \\
\hline Depreciation rate, $\%$ & 10 \\
\hline
\end{tabular}

Year depreciation costs:

$A_{\text {year }}=0.1 \times 5000000=500000$ rubles

\section{Total costs}

Total costs if use water as watering agent:

$C_{\text {total }}^{1}=1580322.6+538890+465760+1775000+408250+0+50000=5268222.6$ rubles Total costs if use proposed solution as watering agent:

$C_{\text {total }}^{2}=612375+208819,9+174660+665625+$

$+153093.8+1437750+500000=3752323.7$ rubles

Economic effect:

\section{$E E=5268222.6-3752323.7+1515898.9$ rubles}

The results of assessing the economic efficiency of the project are summarized in Table 9.

Consequently, in the case of application of the proposed solution and dust suppression technology on the quarry complex technological roads, the enterprise will save more than 1.5 million rubles (or more than 17000 euros) annually.

\section{SWOT analysis}

SWOT analysis is a strategic planning method for identifying and structuring the factors of the internal and external environment of the organization into four categories, depending on their influence:

Strengths - strengths of the internal environment;

Weaknesses - weaknesses of the internal environment;

Opportunities - opportunities related to the external market; Threats - threats associated with the external market.

The SWOT analysis of the evaluated project is shown in Table 10.

The analysis shows that the strengths of the project include the advantages in terms of economic efficiency and safety, both for the environment and for workers, in comparison with current situation.

It can be stated, that 3 problems associated with excessive dust formation and dust suppression are being solved at once:

1. the load on the air environment in the immediate vicinity of the enterprise and on its territory is reduced (including in nearby settlements);

2. there is an improvement in the working conditions of employees and the improvement of their workplaces by reducing dust formation;

3. these effects are also achieved simultaneously with the economic benefit from the use of the proposed solution in the project, which is often a decisive factor for the management of the organization.

The weaknesses of the project included all the factors that would entail additional labor and financial costs, as well as those that would require further improvement. So, a short shelf life of the proposed solution was attributed to them, which is justified by its pure organic composition. Therefore, this point of analysis will need to be improved and any additives will need to be developed to increase the solution shelf life.

Table 9: Economic efficiency of new project

\begin{tabular}{|c|c|c|c|c|c|c|}
\hline \multirow{2}{*}{ Cost items } & \multicolumn{2}{|c|}{$\begin{array}{c}\text { Basic variant (Irrigation with } \\
\text { water) }\end{array}$} & \multicolumn{2}{c|}{ Project variant (Irrigation } & \multicolumn{2}{c|}{ Economy (+/-) } \\
\cline { 2 - 7 } & Rubles & $€$ & Rubles & $€$ & Rubles & $€$ \\
\hline 1.Labor, costs & $1,580,322.6$ & 17,559 & $612,375.0$ & 6804 & $-967,947.6$ & $-10,755$ \\
\hline $\begin{array}{c}2 . \text { Fees, insur- } \\
\text { ance, funds }\end{array}$ & $538,890.0$ & 5988 & $208,819.9$ & 2320 & $-330,070.1$ & 3,668 \\
\hline $\begin{array}{c}\text { 3.Electrical, } \\
\text { energy }\end{array}$ & $465,760.0$ & 5175 & $174,660.0$ & 1941 & $-291,100.0$ & 3,234 \\
\hline 4.Diesel, fuel & $1,775,000.0$ & 19,722 & $665,625.0$ & 7396 & $-1,109,375.0$ & 12,326 \\
\hline $\begin{array}{c}\text { 5.Equipment, } \\
\text { maintenance }\end{array}$ & $434,875.0$ & 4,832 & 163,078 & 1812 & $-, 271,797$. & 3,020 \\
\hline $\begin{array}{c}\text { 6.Irrigation, } \\
\text { solution }\end{array}$ & 0.0 & 0 & $1,437,750.0$ & 15975 & $+1,437,750.0$ & +15975 \\
\hline 7.Depreciation & $500,000.0$ & 5556 & $500,000.0$ & 5556 & 0.0 & 0 \\
\hline Total & $5,294,847 ., 6$ & 58832 & $3,762,307.9$ & 41804 & $-, 1,532,539.1$ & -17028 \\
\hline
\end{tabular}


Table 10: SWOT analysis of new irrigation project

\begin{tabular}{|c|c|}
\hline $\begin{array}{l}\text { STRENGTHS } \\
\text { - low price and availability of raw materials for mak- } \\
\text { ing a solution; } \\
\text { - environmentally friendly solution; } \\
\text { - } \text { safety and high efficiency in comparison with other } \\
\text { formulations; } \\
\text { there is no need for large capital investments. }\end{array}$ & $\begin{array}{l}\text { WEAKNESSES } \\
\text { - } \quad \text { short shelf life of the solution; } \\
\text { lack of equipment and an established line for the } \\
\text { production of solution; } \\
\text { lack of experience in handling organic dust sup- } \\
\text { pression solutions. }\end{array}$ \\
\hline $\begin{array}{l}\text { OPPORTUNITIES } \\
\text { - } \begin{array}{l}\text { OPesence of a large number of suppliers of raw } \\
\text { materials; }\end{array} \\
\text { possibility of opening a new direction of trade and } \\
\text { application of the solution / technology for commer- } \\
\text { cial purposes; } \\
\text { no analogues in the market of dust suppression } \\
\text { compositions in the price-quality-efficiency ratio }\end{array}$ & 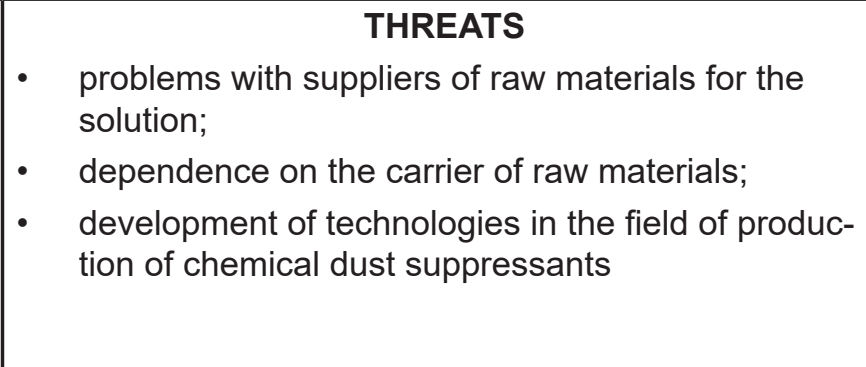 \\
\hline
\end{tabular}

All factors representing the strengths of the project associated with third-party enterprises and suppliers, that is, with the external market, were attributed to the potential opportunities of the project on the external field. Thus, the presence of a large number of suppliers of raw materials creates a competitive environment and will allow purchasing this raw material for production at a lower price in the future. Moreover, there is the possibility of selling the solution / technology for its production to other enterprises in the mining industry and not only, giving the opportunity to take a competitive place in share of dust suppression and labor safety in the market.

Potential threats associated with a project are described by environmental factors, which, in turn, depend more on natural conditions and third-party companies. Thus, unfavorable climatic conditions can lead to crop failure and interruptions in the supply of raw materials. In addition, there is a potential for a breakthrough in the chemical industry and the development of a cheap and safe dust suppression formulation based on polymer binders.

\section{CONCLUSIONS}

The peculiarity of the measures proposed in the project is that a slight increase in the cost of the liquid used for irrigating roads leads to significant changes:

- improved working conditions by increasing the efficiency of dust suppression;

- the workload of one type of employee is reduced, which makes it possible to employ him in other jobs in his field of activity;

- the current costs for the implementation of measures to reduce the dust content of the air in the working area are significantly reduced.

The proposed method of dust suppression using the developed organic binding solution, allows not only to improve the working conditions at the workplaces of the open pit complex of the Alexeevsky cement deposit, by reducing the level of the dust factor impact on the work- ers, but also significantly reduces the costs of measures related to dust suppression on the technological roads of the mine. The use of the proposed method, according to calculations, leads to annual savings of the enterprise in the amount of more than 1.5 million rubles.

\section{REFERENCES}

1. Ilyashenko, I. S., Kovshov, S. V., \& Navitskaite, E. A. (2019). Assessment of the Aerotechnogenic Situation in the City of St. Petersburg Based on Instrumental Measurements of air Dustiness and Computer Modeling of its Distribution. Journal of Ecological Engineering, vol. 20, no. 4, 150-156, DOI: 10.12911/22998993/102808

2. Kazanin, O., Sidorenko, A., Koteleva, N., \& Belova, D. (2020). An assessment of the impact of longwall panel width on the height of complete groundwater drainage in underground thick coal seam mining. Test Engineering and Management, vol. 83, 55685572.

3. Trushko, V.L., Trushko, O.V., \& Potemkin, D.A. (2018b). Efficiency increase in mining of highgrade iron ore deposits with soft ores. International Journal of Mechanical Engineering and Technology, vol. 9, no. 3, 1038-1045.

4. Trushko, O. V., Potemkin, D. A., \& Popov, M. G. (2018a). Ensuring sustainability of mining workings in development of ore deposits in complex geological conditions. ARPN Journal of Engineering and Applied Sciences, vol. 13, no. 7, 2594-2601.

5. Ivanov, A. V., \& Strizhenok, A. V. (2018). Monitoring and reducing the negative impact of halite dumps on the environment. Pollution Research, vol. 37 , no. 1 , 51-55. 
6. Strizhenok, A. V., \& Ivanov, A. V. (2017). Ecological assessment of the current state of environmental components on the territory of the impact of cement production industry. Journal of Ecological Engineering, vol. 18, no.6, 160-165, DOI: $10.12911 / 22998993 / 76850$

7. Nikolaev A.V., \& Tsaplin, A.I. (2017). Heating system for water for mine heating unit. Gornyi Zhurnal, vol. 6, 83-85.

8. Zakirov, D.G., Mukhamedshin, M.A., Faizrakhmanov, R.A., \& Nikolaev, A.V. (2018). Potentiality of energy and ecological efficiency enhancement in mines in the West Ural. Gornyi Zhurnal, vol. 6, 49-52.

9. Ma, Y., Zhou, G., Ding, J., Li, S., \& Wang, G. (2018). Preparation and characterization of an agglomeration-cementing agent for dust suppression in open pit coal mining. Cellulose, vol. 25, no. 7, 4011-4029, DOI: https://doi.org/10.1007/s10570-018-1826-z

10. Zhou, G., Fan, T., Xu, M., Qiu, H., Wang, J., \& Qiu, L. (2018). The development and characterization of a novel coagulant for dust suppression in open-cast coal mines. Adsorption Science \& Technology, vol. 36, no. 1-2, 608-624, DOI: https://doi. org/10.1177\%2F0263617417711025

11. Fan, T., Zhou, G., \& Wang, J. (2018). Preparation and characterization of a wetting-agglomeration-based hybrid coal dust suppressant. Process Safety and Environmental Protection, vol. 113, 282-291, DOI: https://doi.org/10.1016/j.psep.2017.10.023

12. Zhang, H., Nie, W., Yan, J., Bao, Q., Wang, H., Jin, H., Peng, H., Chen, D., Liu, Z., \& Liu, Q. (2020). Preparation and performance study of a novel polymeric spraying dust suppression agent with enhanced wetting and coagulation properties for coal mine. Powder Technology, vol. 364, 901-914, DOI: https://doi.org/10.1016/j.powtec.2019.10.082

13. Jin, H., Nie, W., Zhang, H., Liu, Y., Bao, Q., Wang, H., \& Huang, D. (2019). Preparation and characterization of a novel environmentally friendly coal dust suppressant. Journal of Applied Polymer Science, vol. 136, no. 17, 47354, DOI: https://doi.org/10.1002/ app. 47354

14. Flax Seeds Market - Growth, Trends and Forecast (2020 - 2025). The report on Flaxseed Market. Mordor Intelligence. Available at: https://www.mordorintelligence.com/industry-reports/flaxseeds-market (accessed 28.11.2020).

15. Russia has become a leader in oilseed flax export (2020). Made in Russia. News. 2020-05-15. Available at: https://madeinrussia.ru/en/news/1654 (accessed 28.11.2020).
16. Shim, Y. Y., Olivia, C. M., Liu, J., Boonen, R., Shen, J., \& Reaney, M. J. (2016). Secoisolariciresinol diglucoside and cyanogenic glycosides in gluten-free bread fortified with flaxseed meal. Journal of Agricultural and Food Chemistry, vol. 64, no. 50, 95519558, DOI: https://doi.org/10.1021/acs.jafc.6b03962

17. Wu, S., Wang, X., Qi, W., \& Guo, Q. (2019). Bioactive protein/peptides of flaxseed: A review. Trends in Food Science \& Technology, vol. 92, 184-193, DOI: https://doi.org/10.1016/j.tifs.2019.08.017

18. Bekhit, A. E. D. A., Shavandi, A., Jodjaja, T., Birch, J., Teh, S., Ahmed, I. A. M., Al-Juhaimi, F.Y., Saeedi, P., \& Bekhit, A. A. (2018). Flaxseed: Composition, detoxification, utilization, and opportunities. Biocatalysis and Agricultural Biotechnology, vol. 13, 129-152, DOI: https://doi.org/10.1016/j.bcab.2017.11.017

19. Eurocement group. Official site. Available at: https:// www.eurocement.ru/cntnt/eng10/our_compan2.html (accessed 01.05.2021).

20. Cembureau. The European Cement Association. Official site. Available at: https://cembureau.eu/ about-our-industry/key-facts-figures/ (accessed 01.05.2021)

21. Van den Bosch, M., \& Sang, Å. O. (2017). Urban natural environments as nature-based solutions for improved public health-A systematic review of reviews. Environmental research, vol. 158, 373-384, DOI: https://doi.org/10.1016/j.envres.2017.05.040

22. Raymond, C. M., Frantzeskaki, N., Kabisch, N., Berry, P., Breil, M., Nita, M. R., Geneletti, D., \& Calfapietra, C. (2017). A framework for assessing and implementing the co-benefits of nature-based solutions in urban areas. Environmental Science \& Policy, vol. 77, 15-24, DOI: https://doi.org/10.1016/j.envsci.2017.07.008

23. Maes, J., \& Jacobs, S. (2017). Nature $\square$ based solutions for Europe's sustainable development. Conservation letters, vol. 10, no. 1, 121-124, DOI: https:// doi.org/10.1111/conl.12216

24. Katsubin, A.V., Kovshov, S.V., Ilyashenko, I.S., \& Marinina, V.M. (2020). Study of organic compounds for reduction of the aerotechnogenic load from the coal mines highways. Bezopasnost' Truda v Promyshlennosti, vol. 1, 63-67.

25. Motorservice (2019). Oil consumption and oil loss. Ed. by Motorservice, Technical Market Support. URL: https://cdn2.ms-motorservice.com/fileadmin/ media/MAM/PDF_Assets/Oil-consumption-and-oilloss_51747.pdf

Paper submitted: 26.12.2020.

Paper accepted: 05.05.2021.

This is an open access article distributed under the CC BY 4.0 terms and conditions. 